\title{
Tantangan Mendidik Generasi Milenial Muslim di Era Revolusi Industri 4.0
}

\author{
Sofia Gussevi \\ STAI DR. KH. EZ. Muttaqien Purwakarta \\ sofiagussevi@gmail.com \\ Nur Aeni Muhfi \\ STAI DR. KH. EZ. Muttaqien Purwakarta \\ nuraeni.muhfi@gmail.com
}

DOI: https://doi.org/10.52593/pdg.02.1.05

Naskah diterima: 14 Desember 2020, direvisi: 12 Januari 2021, disetujui: 22 Januari 2021

\begin{abstract}
Abstraksi
Revolusi Industri 4.0 adalah bagaimana teknologi seperti kecerdasan buatan dan internet memengaruhi kehidupan manusia. Teknologi, khususnya internet, memiliki banyak dampak positif tetapi juga dapat merugikan penggunanya jika "tidak pintar" dalam menggunakannya, termasuk dalam hal pendidikan. Keluarga memiliki fungsi yang luas, dan semuanya berhubungan. Misalnya pada bagian agama, dalam fungsi ini keluarga berperan memberikan pengalaman dan pendidikan spiritual kepada anggota keluarga, bagaimana keluarga mengajarkan nilai-nilai yang sejalan dengan ajaran Islam untuk dijadikan sebagai sikap hidup. Keluarga juga mempunyai fungsi pendidikan, sebagai interaksi dalam lingkungan keluarga, orang tua dapat mendidik dan membimbing anaknya dengan baik, dengan kata lain, teladan orang tua menjadi pendidikan yang strategis dalam mengarahkan sikap anak karena perilaku yang baik yang dicontohkan oleh orang tua akan menjadi tolak ukur untuk a anak dalam berbuat baik. Pendidikan dalam keluarga harus berorientasi pada masa depan, artinya pendidikan yang diberikan oleh orang tua kepada anaknya lebih kepada persiapan praktis agar anak dapat menghadapi jaman yang akan dialaminya di masa depan, seperti yang tertuang dalam hadits: "Ketahuilah bahwa kelak anak-anak anda kelak akan mengalami usia yang berbeda dari masa sekarang. "Seringkali orang tua membandingkan kehidupan mereka di masa lalu untuk membuat sebuah" standar nilai "yang harus diterapkan pada anak mereka, meskipun Nabi memperingatkan tentang hal ini dalam hadits. Teknologi khususnya internet yang semakin maju di era sekarang ini menjadi salah satu tantangan dalam mendidik generasi milenial muslim. Penanaman nilai-nilai dalam Alquran diharapkan mampu mengatasi tantangan tersebut. Membekali anak-anak dengan penanaman nilai-nilai agama sejak dini, diharapkan teknologi tidak mempengaruhi generasi milenial muslim, namun sebaliknya generasi milenial muslim dapat menundukkan dan memanfaatkan teknologi.
\end{abstract}

Kata Kunci: Revolusi Industri, Generasi Milenial Muslim, Tantangan Pendidikan 


\section{A. Pendahuluan}

Revolusi Industri 4.0 merupakan konsep yang pertama kali diperkenalkan oleh ekonom asal Jerman, Profesor Klaus Schwab dalam bukunya yang berjudul "The Fourth Industrial Revolution". Klaus mengungkapkan empat tahap revolusi industri yang setiap tahapannya dapat mengubah hidup dan cara kerja manusia, Revolusi Industri 4.0 merupakan tahap terakhir dalam konsep ini setelah tahapan pada abad ke-18, ke-20 dan awal 1970 ${ }^{1}$.

Sebelum datangnya Revolusi Industri 4.0, pembangunan dilakukan secara manual dengan menggunakan otot yang dilakukan oleh manusia dan juga binatang seperti dalam sektor pertanian dan peperangan. Di Jerman tenaga manusia semakin berkurang sehingga digantikan dengan mesin. Berbeda dengan di Indonesia, apabila tidak menggunakan Industri 4.0 maka produk kita tidak bisa bersaing dengan produk luar dan akan tergilas dengan pasar global².

Pendidikan menjadi bagian penting dari konsep hidup dan kehidupan manusia. Dalam perjalanan era industri 4.0 manusia semakin dimanjakan oleh teknolgi yang semakin canggih. Secara terus-menerus terjadinya perubahan peranan dan cara pandang dari manusia di dalam menjalani kehidupan sebagai makhluk sosial. Seiring dengan fenomena tersebut degradasi moral pun semakin marak. Dengan demikian manusia semakin terperosot kedalam kebenaran sesaat ${ }^{3}$.

Membangun generasi penerus bangsa yang berakhlak mulia adalah tanggung jawab semua lini kehidupan, karena sejatinya pendidikan tanggung jawab bersama, tentu saja ini bukan perkara yang mudah. Oleh karena itu diperlukan kesadaran dari semua pihak bahwa pendidikan karakter sangat penting untuk dilaksanakan. Meskipun semua pihak bertanggung jawab atas pendidikan karakter, namun keluarga menjadi pucuk sentral sebagai wahana pertama dalam menanamkan akhlak yang mulia sehingga terbentuk pribadi generasi milenial muslim yang kokoh. Transfer of values berbasis habituasi (transfer ilmu berbasis pembiasaan) merupakan alternatif proses yang harus dilakukan secara berkelanjutan, agar terbentuk karakter anak bersifat individu, mengembalikan nilai-nilai ilahiyah dalam diri kepribadian muslim. (Manpan Drajat, 2015)

\section{B. Teori/ Konsep}

\section{Pengertian Revolusi Industri 4.0}

Revolusi Industri terdiri dari dua kata yaitu revolusi dan industri. Revolusi dalam Kamus Besar Bahasa Indonesia (KBBI) berarti perubahan yang bersifat sangat cepat, sedangkan pengertian industri adalah usaha pelaksanaan proses

\footnotetext{
${ }^{1}$ Qiqi Yuliati Zakiyah, Pembelajaran Integratif dan Holistik di Era Revolusi Industri 4.0 dalam Kapita Selekta Ilmu Pendidikan Islam, (Bandung : Mimbar Pustaka, 2019), 6. Lihat juga dalam Ifham Choli, Pendidikan Agama Islam dan Industri 4.0, Tahdzib Al-Akhlak-PAI-FAI-UIA Jakarta, 2020, 22

${ }^{2}$ Ibid.

${ }^{3}$ Dian Arif Noor Pratama, Tantangan Karakter di Era Revolusi Industri 4.0 dalam Membentuk Kepribadian Muslim, Al-Tanzim, Vol. 03 No. 01, 2019, 201
} 
produksi. Sehingga jika dua kata tersebut dipadukan bermakna suatu perubahan dalam proses produksi yang berlangsung cepat. Perubahan cepat ini tidak hanya bertujuan memperbanyak barang yang diproduksi (kuantitas), namun juga meningkatkan mutu hasil produksi (kualitas) ${ }^{4}$.

Istilah Revolusi Industri diperkenalkan oleh Friedrich Engels dan Louis Anguste Blanqui di pertengahan abad ke-19. Revolusi Industri sedang berjalan dari masa ke masa. Dekade terakhir ini sudah dapat disebut memasuki fase ke empat (4.0). Perubahan fase ke fase memberi perbedaan artikulatif pada sisi kegunaannya. Fase pertama (1.0) bertumpu pada penemuan mesin yang menitikberatkan (stressing) pada mekanisasi produksi. Fase kedua (2.0) sudah beranjak pada tahap produksi massal yang terintegrasi dengan kontrol kualitas (quality control) dan standarisasi. Fase ketiga (3.0) memasuki tahapan keseragaman secara massal yang bertumpu pada integrasi komputerisasi. Fase keempat (4.0) telah menghadirkan digitalisasi dan otomatisasi perpaduan internet dengan manufaktur ${ }^{5}$.

\section{Tantangan Pendidikan Islam di Era Revolusi Industri 4.0}

Perkembangan dunia digital tidak lagi sekedar mempengaruhi, bahkan mengubah perilaku dan kebiasaan masyarakat. Digitalisasi kehidupan yang semakin berkembang pesat ke depan inilah yang mesti dibaca dunia pendidikan sehingga membekali anak-anak kecakapan penting untuk menghadapinya. Pendidikan saat ini mesti membekali anak-anak kecakapan hidup sepuluh hingga dua puluh tahun mendatang. Artinya dunia pendidikan mesti bisa memprediksi dan menyiapkan kecakapan apa yang mesti dimiliki oleh anak untuk hidup di masa depan. Di titik inilah, pendidikan mesti bisa meyesuaikan diri dengan perkembangan pesat di bidang teknologi informasi dan komunikasi dengan mulai membangun sistem pendidikan atau pembelajaran di era digital ${ }^{6}$.

Revolusi digital didasari perkembangan komputer elektronik digital yaitu komputer pribadi dan khususnya mikro prosesor dengan kinerjanya yang terus meningkat, yang memungkinkan teknologi komputer untuk tertanam ke berbagai objek besar dari kamera ke pemutar musik pribadi. Sama pentingnya adalah pengembangan teknologi transmisi termasuk jaringan komputering, internet dan penyiaran digital. Ponsel 3G dan 4G, yang tumbuh pesat penetrasi sosial pada tahun 2000, juga memainkan peran yang sangat besar dalam revolusi digital karena mereka secara bersamaan memberikan hiburan di mana-mana, komunikasi dan konektifitas online. Dalam konteks kondisi pembelajaran yang menyenangkan

\footnotetext{
${ }^{4}$ Choli, Pendidikan Agama..., 24. Dijelaskan juga Revolusi Industri adalah perubahan besar dan radikal terhadap cara manusia memproduksi barang. Perubahan besar ini tercatat sudah terjadi tiga kali, dan saat ini kita sedang mengalami revolusi indutri yang keempat.

${ }^{5}$ Hendra Suwardana, Revolusi Industri 4.0 Berbasis Revolusi Mental, JATI UNIK, Vol. 01, No.02, 2018, 111

${ }^{6}$ Choli, Pendidikan Agama , 24
}

48 | Paedagogie: p-ISSN: 2337-6848, e-ISSN : 2723-5971 
(edutainment), ditegaskan bahwa suatu kegiatan pembelajaran tidak selalu menjamin peserta didik akan dapat belajar. Hal ini menunjukkan bahwa sebaik apapun seorang guru dalam merancang dan mendesain suatu program pembelajaran, tidak akan dapat secara optimal mewujudkan ketercapaian kompetensi yang diharapkan apabila tidak didukung oleh pemilihan sekaligus penggunaan metode secara tepat. Untuk itu peranan masyarakat digital di era Revolusi Industri 4.0 ini menjadi tantangan bagi membangun pendidikan berbasis teknologi informasi yang mampu menjawab tantangan kebutuhan masyarakat era Revolusi Industri 4.0 ini $^{7}$.

Tantangan pada dunia pendidikan dalam menghadapi Revolusi Industri 4.0 adalah penanaman pendidikan nilai. Pendidikan nilai ditujukan untuk mencegah antara lain meningkatnya kasus kejahatan, degradasi moral dan pengunaan obatobatan terlarang oleh generasi muda. Melalui pembelajaran berbasis nilai, siswa dapat menentukan nilai baik dan buruk sehingga dapat memilih nilai baik untuk peningkatan kualitas hidupnya di dalam masyarakat. Tapi pada kenyataannya, semakin pesatnya arus teknologi justru siswa-siswi semakin terlena dan memiliki sikap yang enggan bertanggung jawab, degradasi moral dan meningkatnya kasus kejahatan di kalangan siswa. Dengan adanya aplikasi media sosial mempermudah mengakses informasi dan komunikasi mengakibatkan kejahatan di media online. Hal ini dikarenakan kurangnya pendidikan nilai dan tantangan bagi pendidik untuk menguatkan karakter moral siswa agar tidak terjerumus dan terlena dengan pesatnya teknologi industri $4.0^{8}$.

Menurut Akhmad Syahri dalam jurnal yang berjudul "Spirit Islam dalam Teknologi Pendidikan di Era Revolusi Industri 4.0”, nilai-nilai yang mulai tergerus akibat transformasi industri $4.0^{9}$ antara lain :

1. Nilai kultural. Nilai kultural adalah nilai yang berhubungan dengan budaya, karakteristik lingkungan sosial dan masyarakat. Pendidikan dapat menolong siswa untuk melihat nilai-nilai kultural sosial secara sistematis dengan cara mengembangkan keseimbangan yang sehat antara sikap terbuka (openness) dan tidak mudah percaya (skepticism).

2. Nilai yuridis formal. Nilai yuridis formal adalah nilai yang berkaitan dengan aspek politik, hukum dan ideologi. Nilai sosial politik suatu bahan ajar merupakan kandungan nilai yang dapat memberikan petunjuk kepada manusia untuk bersikap dan berperilaku sosial yang baik atau pun berpolitik yang baik dalam kehidupannya.

3. Nilai religius. Mempertahankan nilai-nilai tersebut merupakan tantangan terberat dalam menghadapi Revolusi Industri 4.0. Perkembangan zaman

${ }^{7}$ Ibid., 25

${ }^{8}$ Nur Hidayat, Peran dan Tantangan Pendidikan Agama Islam di Era Global, Jurnal el-Tarbawi, Vol. XIII, No. 2, 2015, 135-137

${ }^{9}$ Akhmad Syahri, Spirit Islam dalam Teknologi Pendidikan di Era Revolusi Industri 4.0, Jurnal Attarbiyah, Vol. 28, 2018, 62 
menuntut manusia lebih kreatif karena pada dasarnya zaman tidak bisa dilawan. Revolusi Industri 4.0. banyak menggunakan jasa mesin dibandingkan manusia. Tetapi ada hal penting yang membedakan mesin dengan manusia yaitu dari segi nilai kemanusiaan yang tidak dimiliki oleh mesin. Penanaman nilai inilah yang perlu diperkuat untuk mengangkat harkat dan martabat dunia pendidikan.

Apabila ditilik lebih jauh, sebenarnya Revolusi Industri 4.0 tidak hanya mengubah tatanan budaya dan pola kehidupan masyarakat, melainkan juga mendorong munculnya berbagai gagasan baru dalam segi keagamaan (religiusitas), spiritualitas serta nilai-nilai sosial kehidupan. Islam sebagai agama rahmatan lil 'aalamiin (religiusitas) menjadi hal penting untuk menanggapi perkembangan zaman. Realitanya pendidikan Islam kurang mendorong munculnya pemikiran kritis. Padahal Islam dapat menjawab segala tantangan perubahan zaman, karena pedomannya yang jelas yaitu al-Qur'an dan al-Sunnah. Apabila zaman berkembang dengan kekuatan teknologi global, maka banyak sekali peluang yang dapat diambil dalam pendidikan Islam khususnya. Islam dapat memunculkan dirinya sebagai sebuah keunggulan di tengah keanekaragaman global, terutama di dunia pendidikan. Media dan teknologi informasi adalah sarana berbagi untuk mendapatkan informasi baik dan bermanfaat. Tanpa adanya penyeimbangan sisi religiusnya maka informasi yang beredar akan kurang bernilai. Dapat dilihat dalam konten penayangan oleh media informasi sekarang lebih banyak menampakkan hal negatif di dalam iklan, film, serta produk hiburan lainnya. Dalam hal ini pentingnya pengembangan budaya kritis dan religius yang tetap bisa memenuhi kebutuhan hiburan dan selera estetika dalam perkembangan media-media era sekarang ${ }^{10}$.

Mengenai peran Islam yang dapat dilakukan terhadap perkembangan IPTEK, setidaknya ada dua hal yang perlu diperhatikan ${ }^{11}$ yaitu :

1. Aqidah Islam harus dijadikan basis segala konsep dan aplikasi IPTEK. Paradigma ini yang harus dikembangkan oleh kaum muslim saat ini. Banyak pendidikan yang berlangsung dengan kemajuan teknogi pendidikan yang menghindari kebenaran aqidah Islam, layaknya pendidikan berbasis sekuler.

2. Syari'ah Islam sebagai standar pemanfaatan IPTEK. Standar syari'ah yang diberikan untuk memanfaatkan IPTEK adalah tentang halal haram. IPTEK yang dibolehkan untuk dimanfaatkan adalah IPTEK yang dihalalkan syari'ah.

Pendidikan Islam mengajarkan bahwa globalisasi mendorong manusia khususnya umat beragama untuk mampu menangkap peluang dan menghadapi tantangan pada era Revolusi Industri 4.0 ini. Hal ini karena permasalahan

${ }^{10}$ Choli, Pendidikan Agama..., 31

${ }^{11}$ Ibid., 32. 
pembangunan peradaban bukan dari ajaran agama melainkan manusianya. Pendidikan justru mendukung pengembangan ilmu dan teknologi. Era Revolusi Industri 4.0 tidak perlu dianggap ancaman bagi agama, sebaliknya agama bukanlah ancaman terhadap Revolusi Industri 4.0. Dalam kaitan ini perlu ditekankan pentingnya mengharmoniskan ilmu pengetahuan dan teknologi (IPTEK) dengan agama. IPTEK harus selalu dilandasi oleh nilai-nilai moral agama agar tidak bertolak belakang terhadap nilai-nilai kemanusiaan. Sedangkan ajaran Islam harus didekatkan dengan konteks modernitas, sehingga dapat bersifat compatible (cocok) dengan segala waktu dan tempat ${ }^{12}$.

Dalam menghadapi hal tersebut, untuk sukses di era Revolusi Industri 4.0 dituntut bersifat ${ }^{13}$ sebagai berikut :

a. Harus menjadi anak bangsa yang kreatif, agar bisa menjadi sangat mandiri.

b. Harus menjadi anak bangsa yang inovatif, agar sukses dalam usaha berbasis kreatifitasnya sendiri.

c. Harus menjadi anak bangsa yang inklusif, yang bisa berkolaborasi lintas etnik, budaya dan agama, sehingga pandangan dunianya tidak sempit.

Dengan demikian, dalam menghadapi era Revolusi Industri 4.0 dituntut untuk menjadi orang-orang kreatif ${ }^{14}$ dan inovatif, walaupun secara teoritik tidak ada mata pelajaran atau mata kuliahnya. Sehingga mampu menghadapi dan berhasil melalui segala tantangan yang ditemui di era ini.

Industri 4.0 memiliki potensi manfaat yang besar namun juga memiliki tantangan yang besar jika tidak bijak dalam menghadapinya. Dengan era serba ada dan canggih ini manusia semakin dimanjakan oleh teknologi, manusia semakin berfikir dengan serba instan, dengan begitu karakter manusia semakin tergerus oleh zaman. Sehingga era Industri 4.0 menjadi problem manusia yang tidak bijak dalam menghadapi era ini. Dengan mudahnya akses internet, banyak tontonan yang tidak layak menjadi tuntunan masyarakat yang khususnya peserta

12 Ibid., 33

${ }^{13}$ Ibid., 34

${ }^{14}$ Menurut JP Guilford, sebagaimana dikutip oleh Ifham Choli, seorang yang keratif akan memiliki ciriciri sebagai berikut : Flexibility, yaitu memiliki kemampuan keluar dari tradisi dan kebiasaan, untuk mendapatkan ide baru, kebedaan dan hasil-hasil yang tidak biasa; Fluency, yaitu memiliki kemampuan berfikir banyak ide dan banyak alternatif penyelesaian problem; Elaboration, yaitu memiliki kemampuan untuk bekeja detail dari setiap ide dan solusi; Tolerance and ambiguity, yaitu memiliki kemampuan untuk merekonsialiasi berbagai ide yang bertentangan satu sama lain, tanpa melahirkan ketegangan baru; Originality, yaitu memiliki kemampuan melahirkan ide-ide, pemikiran, model, yang benar-benar baru, berbeda dengan yang lain, dan mampu melahirkan sesuatu yang benar-benar di luar yang sudah ada; Sensitivity, yaitu memiliki kepekaan terhadap permasalahan yang muncul di lingkungannya; Curiosity, yaitu memiliki sikap terbuka terhadap masukan-masukan baru, informasi-informasi baru, dan memiliki keinginan kuat untuk menggunakan berbagai informasi yang dimilikinya itu untuk menyelesaikan permasalahan yang dihadapinya; Indepedence, yaitu memiliki kemampuan untuk berfikir dan memikirkan permasalahan dengan kemauannya sendiri; Action, yaitu memiliki kemampuan untuk mewujudkan ide-idenya menjadi kenyataan, dengan antusias dan energetic; Commitment, yaitu memiliki komitmen dan kepedulian yang tinggi untuk menyelesaikan permasalahan dengan ide dan cara-cara baru. 
didik yang masih mencari jati diri, hampir semua sibuk dengan handphone masing-masing karena ingin mengekspresikan dirinya di sosial media. Guru yang harusnya dihormati dalam pendidikan menjadi teman tanpa batas, akhirnya tidak ada sopan santun yang tertanam dalam peserta didik, karena hilangnya akhlak mulia dalam diri mereka.

Pembelajaran di era teknologi mampu mengubah cara pandang hidup dan mampu membawa kepada interaksi dunia yang positif dan bahkan juga negatif. Jika teknologi yang mampu memberikan apa saja yang diinginkan manusia secara instan lebih dihargai dibandingkan peran guru sebagai pusat belajar dalam menuntuti lmu. Maka dengan fenomena tersebut seharusnya masyarakat atau peserta didik harus lebih ditingkatkan dalam spiritualitas melalui habituasi (pembiasaan) sehingga mampu mengantarkan pada karakter baik ${ }^{15}$.

\section{Metodologi Penelitian/ Kajian}

Metode yang dilakukan dalam melakukan penelitian ini adalah kualitatif deskriptif dengan pendekatan kajian konten/ kepustakaan. Adapun sumber dalam penelitian ini adalah kajian perubahan sosial generasi milineal muslim di era digital (revlolusi industri 4.0) dengan menggunakan analisa teori Friedrich Engels dan Louis Anguste Blanqui tentang teori generasi dan revolusi industri.

\section{Hasil dan Pembahasan}

Generasi milenial atau generasi muda ditandai oleh peningkatan penggunaan dan keakraban dengan komunikasi, media, dan teknologi digital. Pada "zaman now", generasi milenial itu tidak hanya cerdas tetapi harus memiliki akhlak yang baik. Dengan demikian, generasi milenial muslim atau generasi muslim milenial adalah generasi muda muslim yang terikat oleh cara memandang dunia bahwa keimanan dan modernitas bisa berjalan beriringan.

Pembentukan kepribadian muslim pada dasarnya merupakan upaya untuk mengubah sikap ke arah kecenderungan pada nilai keislaman. Karena ciri khas kepribadian muslim yaitu terwujudnya tingkah laku mulia sesuai dengan tuntunan Allah SWT. (berakhlak mulia). Dalam perspektif Islam, akhlak mulia merupakan buah yang dihasilkan dari proses pengimplementasian syari'ah yang dilandasi oleh pondasi aqidah yang kokoh. Dengan demikian tidak mungkin akhlak mulia akan terwujud pada diri seseorang jika ia tidak memiliki aqidah dan syari'ah yang benar, karena aqidah yang benar terefleksikan pada sikap dan perilaku sehari-hari manusia dalam mewujudkan pribadi muslim.

Pendidikan umumnya berarti daya upaya untuk menunjukkan tumbuhnya budi pekerti (kekuatan batin, karakter), pikiran (intelek) dan tubuh anak ${ }^{16}$. Pondasi akhlak atau budi pekerti menjadi penting, karena manusia sebagai makhluk sosial tidak akan

\footnotetext{
${ }^{15}$ Pratama, Tantangan Karakter..., 213

${ }^{16}$ Anang Abdul Razak, Pilar-Pilar Pendidikan dalam Keluarga, Jurnal Paedagogi, Vol. 01 No. 03, 2013, 123
} 
terlepas dari lingkungan sosialnya, akhlak lebih utama dibandingkan pikiran, karena tidak sedikit orang yang cerdas akan tetapi tidak memiliki pondasi akhlak yang baik.

Melihat perkembangan Revolusi Industri 4.0 yang berjalan sekarang ini, terutama digitalisasi menjadi tantangan juga bagi dunia pendidikan termasuk pendidikan Islam. Sebenarnya esensi pendidikan itu sendiri adalah adanya proses transfer nilai, pengetahuan dan keterampilan dari generasi tua kepada generasi muda agar generasi muda mampu hidup ${ }^{17}$. Dalam Islam ditegaskan bahwa pendidikan hendaknya serba meliputi, sebagaimana yang terungkap dalam al-Qur'an surat Luqman sebagai berikut :

13. Dan (ingatlah) ketika Luqman berkata kepada anaknya, waktu ia memberi pelajaran kepadanya : "Hai anakku, janganlah kamu mempersekutukan Allah, sesungguhnya mempersekutukan (Allah) adalah benar-benar kezaliman yang besar"

14. Dan Kami perintahkan kepada manusia (berbuat baik) kepada dua orang ibubapanya; ibunya telah mengandungnya dalam Keadaan lemah yang bertambahtambah, dan menyapihnya dalam dua tahun. Bersyukurlah kepadaku dan kepada dua orang ibu bapakmu, hanya kepada-Kulah kembalimu.

15. Dan jika keduanya memaksamu untuk mempersekutukan dengan aku sesuatu yang tidak ada pengetahuanmu tentang itu, maka janganlah kamu mengikuti keduanya, dan pergaulilah keduanya di dunia dengan baik, dan ikutilah jalan orang yang kembali kepada-Ku, kemudian hanya kepada-Kulah kembalimu, maka Kuberitakan kepadamu apa yang telah kamu kerjakan.

16. (Luqman berkata): "Hai anakku, Sesungguhnya jika ada (sesuatu perbuatan) seberat biji sawi, dan berada dalam batu atau di langit atau di dalam bumi, niscaya Allah akan mendatangkannya (membalasinya). Sesungguhnya Allah Maha Halus lagi Maha mengetahui.

17. Hai anakku, dirikanlah shalat dan suruhlah (manusia) mengerjakan yang baik dan cegahlah (mereka) dari perbuatan yang mungkar dan bersabarlah terhadap apa yang menimpa kamu. Sesungguhnya yang demikian itu termasuk hal-hal yang diwajibkan (oleh Allah).

18. Dan janganlah kamu memalingkan mukamu dari manusia (karena sombong) dan janganlah kamu berjalan di muka bumi dengan angkuh. Sesungguhnya Allah tidak menyukai orang-orang yang sombong lagi membanggakan diri.

19. Dan sederhanalah kamu dalam berjalan dan lunakkanlah suaramu. Sesungguhnya seburuk-buruk suara ialah suara keledai.

20. Tidakkah kamu perhatikan sesungguhnya Allah telah menundukkan untuk (kepentingan)mu apa yang di langit dan apa yang di bumi dan menyempurnakan untukmu nikmat-Nya lahir dan batin dan di antara manusia ada yang membantah tentang (keesaan) Allah tanpa ilmu pengetahuan atau petunjuk dan tanpa kitab yang memberi penerangan.

21. Dan apabila dikatakan kepada mereka: "Ikutilah apa yang diturunkan Allah". mereka menjawab: "(Tidak), tapi kami (hanya) mengikuti apa yang kami dapati bapak-bapak kami mengerjakannya". dan Apakah mereka (akan mengikuti bapakbapak mereka) walaupun syaitan itu menyeru mereka ke dalam siksa api yang menyala-nyala (neraka)?

${ }^{17}$ Malik Fajar, Holistik Pemikiran Pendidikan, (Jakarta : RajaGrafindo Persada, 2005), 113 
22. Dan barangsiapa yang menyerahkan dirinya kepada Allah, sedang dia orang yang berbuat kebaikan, maka sesungguhnya ia telah berpegang kepada buhul tali yang kokoh dan hanya kepada Allah-lah kesudahan segala urusan.

23. Dan barangsiapa kafir maka kekafirannya itu janganlah menyedihkanmu. hanya kepada Kami-lah mereka kembali, lalu Kami beritakan kepada mereka apa yang telah mereka kerjakan. Sesungguhnya Allah Maha mengetahui segala isi hati.

24. Kami biarkan mereka bersenang-senang sebentar, kemudian Kami paksa mereka (masuk) ke dalam siksa yang keras.

25. Dan sesungguhnya jika kamu tanyakan kepada mereka: "Siapakah yang menciptakan langit dan bumi?" tentu mereka akan menjawab: "Allah". Katakanlah : "Segala puji bagi Allah", tetapi kebanyakan mereka tidak mengetahui.

26. Kepunyaan Allah-lah apa yang di langit dan yang di bumi. Sesungguhnya Allah Dia-lah yang Maha Kaya lagi Maha Terpuji.

27. Dan seandainya pohon-pohon di bumi menjadi pena dan laut (menjadi tinta), ditambahkan kepadanya tujuh laut (lagi) sesudah (kering)nya, niscaya tidak akan habis-habisnya (dituliskan) kalimat Allah. Sesungguhnya Allah Maha Perkasa lagi Maha Bijaksana.

28. Tidaklah Allah menciptakan dan membangkitkan kamu (dari dalam kubur) itu melainkan hanyalah seperti (menciptakan dan membangkitkan) satu jiwa saja. Sesungguhnya Allah Maha mendengar lagi Maha melihat.

29. Tidakkah kamu memperhatikan, bahwa sesungguhnya Allah memasukkan malam ke dalam siang dan memasukkan siang ke dalam malam dan Dia tundukkan matahari dan bulan masing-masing berjalan sampai kepada waktu yang ditentukan, dan sesungguhnya Allah Maha mengetahui apa yang kamu kerjakan.

30. Demikianlah, karena sesungguhnya Allah, Dia-lah yang hak dan Sesungguhnya apa saja yang mereka seru selain dari Allah itulah yang batil dan sesungguhnya Allah Dialah yang Maha Tinggi lagi Maha besar.

31. Tidakkah kamu memperhatikan bahwa sesungguhnya kapal itu berlayar di laut dengan nikmat Allah, supaya diperlihatkan-Nya kepadamu sebahagian dari tanda-tanda (kekuasaan)-Nya. Sesungguhnya pada yang demikian itu benarbenar terdapat tanda-tanda bagi semua orang yang sangat sabar lagi banyak bersyukur.

32. Dan apabila mereka dilamun ombak yang besar seperti gunung, mereka menyeru Allah dengan memurnikan ketaatan kepada-Nya Maka tatkala Allah menyelamatkan mereka sampai di daratan, lalu sebagian mereka tetap menempuh jalan yang lurus dan tidak ada yang mengingkari ayat-ayat Kami selain orangorang yang tidak setia lagi ingkar.

33. Hai manusia, bertakwalah kepada Tuhanmu dan takutilah suatu hari yang (pada hari itu) seorang bapak tidak dapat menolong anaknya dan seorang anak tidak dapat (pula) menolong bapaknya sedikitpun. Sesungguhnya janji Allah adalah benar, maka janganlah sekali-kali kehidupan dunia memperdayakan kamu, dan jangan (pula) penipu (syaitan) memperdayakan kamu dalam (mentaati) Allah.

34. Sesungguhnya Allah, hanya pada sisi-Nya sajalah pengetahuan tentang hari kiamat dan Dia-lah yang menurunkan hujan, dan mengetahui apa yang ada dalam rahim dan tiada seorangpun yang dapat mengetahui (dengan pasti) apa yang akan diusahakannya besok dan tiada seorangpun yang dapat mengetahui di bumi 
mana dia akan mati. Sesungguhnya Allah Maha mengetahui lagi Maha Mengenal ${ }^{18}$.

Sebenarnya ayat di atas menggambarkan seseorang yang bernama Luqman dalam mendidik anaknya. Kisah tersebut mengungkapkan bahwa secara umum dalam mendidik hendaknya memberikan penyadaran potensi fitrah keagamaan, menumbuhkan, mengelola dan membentuk wawasan, akhlak serta tingkah laku yang sesuai dengan ajaran Islam, menggerakkan dan menyadarkan manusia untuk senantiasa beramal shaleh dalam rangka beribadah kepada Allah.

Keluarga sebagai basis terdepan dalam membina pribadi dan masyarakat, baik dan buruknya seseorang akan berbanding lurus dengan pembinaan yang dilakukan dalam lingkup keluarga. Orang tua memiliki peran sentral, karena orang tua sesungguhnya merupakan madrasatul ula. Orang tua terutama ibu menjadi sekolah pertama bagi anaknya. Pendidikan yang diperoleh seorang anak dalam lingkungan keluarga merupakan pendidikan yang paling utama, karena peranan orang tua dalam mempengaruhi pembentukan karakter seorang anak.

Mengenai peran keluarga baik ayah maupun ibu dalam mendidik anak-anak mereka, tergambar dalam firman Allah :

"Hai orang-orang yang beriman, peliharalah dirimu dan keluargamu dari api neraka yang bahan bakarnya adalah manusia dan batu; penjaganya malaikatmalaikat yang kasar, keras, dan tidak mendurhakai Allah terhadap apa yang diperintahkan-Nya kepada mereka dan selalu mengerjakan apa yang diperintahkan"19.

Dari ayat di atas dapat dipahami bahwa mendidik dan membimbing anak dalam keluarga tersebut bukan merupakan tanggung jawab ibu saja, tetapi ayah juga sebagai kepala keluarga walaupun sudah lelah dalam mencari nafkah, tetap bertanggung jawab terhadap pendidikan anak mereka. Jadi ayah dan ibu dalam keluarga samasama bertanggung jawab terhadap keluarga mereka, termasuk terhadap pendidikan anak mereka.

Berkaitan dengan hal itu, keluarga mempunyai fungsi yang sangat luas, dan saling terkait. Di antaranya sebagai fungsi religius, pada fungsi ini keluarga mempunyai peran untuk memberikan pengalaman dan pendidikan keagamaan kepada anggota keluarganya, keluarga mengajarkan tentang nilai-nilai yang selaras dengan ajaran Islam untuk dijadikan sebagai sikap hidup ${ }^{20}$.

Selain itu, keluarga juga memiliki fungsi edukatif, sebagai interaksi dalam lingkup keluarga, orang tua mampu mendidik dan membimbing anaknya dengan baik, dengan kata lain teladan orang tua menjadi pendidikan yang strategis dalam

${ }^{18}$ QS. Luqman : 13-34

${ }^{19}$ QS. al-Tahrim : 6

${ }^{20}$ Fajar, Holistik Pemikiran ..., 119 
mengarahkan sikap anak, karena perilaku yang baik yang dicontohkan oleh orang tua akan menjadi ukuran bagi seorang anak dalam berbuat baik ${ }^{21}$.

Menurut Ryan dan Lickona sebagaimana dikutip oleh Sri Lestari ${ }^{22}$, orang tua memiliki sumbangan terhadap karakter anak antara lain melalui lima cara. Pertama, dengan menyayangi anak, orang tua membantu anak untuk merasakan dirinya berharga. Kedua, orang tua menjadikan dirinya sebagai model bagi anak dalam memperlakukan orang lain. Ketiga, hubungan yang hangat antara orang tua dan anak menjadi kekuatan dalam menghadapi pengaruh moral. Keempat, kasih sayang berperan dalam perkembangan penalaran moral. Kelima, kasih sayang mendorong terjadinya komunikasi orang tua-anak yang menjadi variabel mediator antara kasih sayang dan perkembangan penalaran moral.

Pendidikan dalam keluarga seharusnya juga beriontasi pada masa depan, artinya pendidikan yang diberikan oleh orang tua kepada anaknya lebih kepada persiapanpersiapan praktis agar anak mampu menghadapi zaman yang akan dialaminya di kemudian hari, seperti yang diungkapkan dalam hadits : "Ketahuilah bahwa anakanakmu kelak akan mengalami zaman yang berbeda dengan zaman sekarang”. Tetapi dalam realitanya seringkali orang tua membanding-bandingkan kehidupannya di masa lalu menjadikan "standar nilai" yang harus diterapkan juga pada anaknya, padahal Rasul sudah mewanti-wanti hal itu dalam hadits tersebut.

\section{E. Simpulan}

Berdasarkan paparan di atas, maka dapat diambil beberapa kesimpulan yaitu: pertama, memasuki era Revolusi Industri 4.0. (fase keempat) yang menghadirkan digitalisasi dan otomatisasi perpaduan internet dengan manufaktur, tidak lagi sekedar mempengaruhi, bahkan mengubah perilaku dan kebiasaan masyarakat. Digitalisasi kehidupan ini semakin terus berkembang pesat; kedua, teknologi terutama internet yang semakin maju pada era sekarang ini merupakan tantangan dalam mendidik generasi milenial muslim. Membekali anak dengan penanaman nilai-nilai agama diharapkan bukan teknologi yang mempengaruhi generasi milenial muslim tetapi sebaliknya generasi milenial muslim tersebutlah yang mampu menundukkan dan memanfaatkan teknologi. Dengan demikian adanya teknologi yang bervariasi,

${ }^{21}$ Ibid. Lihat juga dalam Usfitriyah, Islamic Parenting (Pengasuhan Anak dalam Islam), Kompas, 8 Oktober 2016. Di dalam referensi lain, hal ini dijelaskan bahwa orang tua bertanggung jawab untuk memenuhi kebutuhan anaknya, mengajari, mengarahkan dan mendidik. Tanggungjawab orang tua meliputi tanggung jawab keimanan, materi, fisik, moral, akal, kejiwaan, sosial dan seks.Tanggung jawab ini lah yang disebut bentuk pengasuhan. Tujuan dari pengasuhan itu sendiri adalah untuk membentuk anak-anak menjadi manusia yang sehat, cerdas, berkarakter mulia, berakhlak serta mampu memjadi generasi yang kuat dan memiliki masa depan yang cerah bukan generasi yang lemah. Mengenai tanggung jawab orang tua ini juga diungkapkan oleh Sofia Gussevi, Manajemen Konflik dalam Rumah Tangga Isteri yang Bekerja, Jurnal Muttaqien, Vol. 01 No. 01, Juli 2020, 69. Hal yang sama juga dipaparkan oleh Melinda Maulani, Pola Asuh Anak Wanita Karir, Skripsi, (Purwakarta : STAI DR. KH. EZ. Muttaqien, 2020), 2

${ }^{22}$ Sri Lestari, Psikologi Keluarga : Penanaman Nilai Penanganan Konflik dalam Keluarga, (Jakarta : Prenadamedia, 2012), 96 
seseorang justru memiliki banyak pilihan untuk menebar hal positif, misalnya memanfaatkan teknologi itu untuk mengajarkan orang lain dalam menghayati nilainilai yang terkandung dalam al-Qur'an; dan ketiga, akhlak yang baik yang berkesinambungan dengan proses habituasi (pembiasaan) merupakan action (tindakan) terpenting dalam mengimplementasikan nilai. Oleh karena itu, peran keluarga adalah universitas utama dalam mewujudkan generasi milenial muslim yang berkualitas. Perubahan zaman yang dihadapi dijadikan sebagai tantangan yang harus diatasi dan dianggap sebagai peluang untuk dimanfaatkan, bukan dianggap sebagai ancaman.

\section{Daftar Pustaka}

Choli, Ifham. 2020. Pendidikan Agama Islam dan Industri 4.0, Jurnal Tahdzib AlAkhlak-PAI-FAI-UIA Jakarta

Fajar, Malik. 2005. Holistik Pemikiran Pendidikan, Jakarta : RajaGrafindo Persada

Gussevi, Sofia. 2020. Manajemen Konflik dalam Rumah Tangga Isteri yang Bekerja, Jurnal Muttaqien, Vol. 01 No. 01, Juli 2020

Hidayat, Nur. 2015. Peran dan Tantangan Pendidikan Agama Islam di Era Global, Jurnal el-Tarbawi, Vol. XIII, No. 2

Lestari, Sri. 2012. Psikologi Keluarga : Penanaman Nilai Penanganan Konflik dalam Keluarga, Jakarta : Prenadamedia

Manpan Drajat, M. R. E. (2015). Etika Ptrofesi Guru. Alfabeta.

Effendi, M. Ridwan dan Manpan Drajat. Etika Profesi Guru. Cet. I: Bandung; Alfabeta, 2014.

Maulani, Melinda. 2020. Pola Asuh Anak Wanita Karir, Skripsi, Purwakarta : STAI DR. KH. EZ. Muttaqien

Pratama, Dian Arif Noor. 2019. Tantangan Karakter di Era Revolusi Industri 4.0 dalam Membentuk Kepribadian Muslim, Jurnal Al-Tanzim, Vol. 03 No. 01

Razak, Anang Abdul. 2013. Pilar-Pilar Pendidikan dalam Keluarga, Jurnal Paedagogi, Vol. 01 No. 03

Suwardana, Hendra. 2017. Revolusi Industri 4.0 Berbasis Revolusi Mental, Jurnal JATI UNIK, Vol. 1, No. 2

Syahri, Akhmad. 2018. Spirit Islam dalam Teknologi Pendidikan di Era Revolusi Industri 4.0, Jurnal Attarbiyah, Vol. 28

Usfitriyah, Islamic Parenting (Pengasuhan Anak dalam Islam), Kompas, 8 Oktober 2016

Zakiyah, Qiqi Yuliati. 2019. Pembelajaran Integratif dan Holistik di Era Revolusi Industri 4.0 dalam Kapita Selekta Ilmu Pendidikan Islam, Bandung : Mimbar Pustaka 